\title{
The Principle and Significance of Ideological and Political Work in Colleges under the New Situation
}

\author{
Shuang Guan \\ Harbin Finance University, Heilongjiang, Harbin
}

Keywords: Ideological and political work in colleges; Working principle; Meaning

\begin{abstract}
The General Secretary Xi Jinping pointed out the importance of ideological and political work in colleges to the development of colleges in China under the new situation. He expounded the meaning and the fundamental direction of ideological and political work in colleges, and emphasized the principle of ideological and political work in colleges. Around the speech of General Secretary Xi Jinping, to start the understanding on the principles and significance of ideological and political work.

Under the social situation of focusing on development, in order to promote the development of the party and state and realize the overall strategy of the great rejuvenation of China, General Secretary Xi Jinping made an important speech at the ideological and political conference in colleges nationwide. He profoundly answered a series of major questions about the ideological and political work and Higher Education development, put forward the views on strengthening and improving the ideological and political work. China's colleges shoulder the important mission including personnel training, scientific research, social service, cultural inheritance innovation, international exchange and cooperation. The quality of ideological and political work in colleges is related to the quality of socialism heirs with Chinese characteristics. Therefore, the school should pay more attention to ideological and political work, to clarify the importance and objectives of ideological and political work, to strengthen the ideological and theoretical education and value leading, to speed up the construction of university teacher teams, improve the party's leadership to colleges, through continuous innovation and reform of ideological and political work, to make a new interpretation on the significance of ideological and political work, to explore the principles of the ideological and political work under the new situation, so as to promote the development of ideological and political work in colleges.
\end{abstract}

\section{The Significance of Ideological and Political Work in Colleges under the New Situation}

The development of higher education is an important symbol of national development level, in order to improve the development level of higher education in our country and enhance the core competitiveness of our country, the colleges must strengthen the reform of ideological and political work so as to promote the leading role of ideological and political work in the development of colleges. In his speech, the Chairman Xi Jinping stressed that the ideological and political work in colleges is related to what kind of people are cultivated in colleges, how to cultivate people and who will re responsible for this work for these fundamental problems. This reveals the dialectical relationship between the ideological and political work in the development of higher education, and puts forward new ideas for comprehensively strengthen and improve the ideological and political work in colleges, which opens up a new situation and sets up principles for the development of higher education in our country.

First, the urgency of the new situation at home and abroad on the strengthening and improvement of China's ideological and political work. With the social and economic development of all countries, the world pattern is gradually changing, transformed from unipolar to multipolarization, the overall environment tends to peaceful development, the social, economic, political and other areas of communication in the world are increasingly frequent, while with the rapid development of the market economy, the core values of the socialist market are eroded by the profitability of market, the Western capitalist countries still do not change the attack of sugar-coated bullets, which makes our society to appear money worship, hedonism these bad ideas. Marxist 
guiding ideology is facing the impact and deconstruction of the diversified social trend of thought. Colleges are the important place of our party to develop socialist ideology. Under such social background, colleges must strengthen ideological and political education and attach importance to moral education function of ideological and political work, correctly guide the students' values, and ensure the correctness of the direction of the national pillars cultivated by the university.

Second, the inevitability of China's education policy and development reform to improve the ideological and political work in colleges. Since the founding of the PRC, China's higher education has attached great importance to moral education. In the report of the 18th National Congress of the Communist Party of China (CPC), it pointed out that the education serving for the socialist modernization construction and the people, the moral education is treated as a fundamental task of education, to cultivate moral, intellectual and aesthetic development of socialism and successors. A new generation of college students growing environment is good, less experiencing suffering, their thinking is active, vision is wide, dare to accept new things, willing to innovate and challenge, but also more self-centered, sense of responsibility and collective consciousness is weak, we must guide their ideological and moral direction through the ideological and political work in colleges, to avoid the confusion of their values. General Secretary Xi Jinping said in his speech, China's higher education must adhere to the correct political direction, establishing value concept and cultivating talents must be the center link. It can be seen that the development of college education is inseparable from the moral education work, college teachers should recognize the internal unity of the moral education work and ideological and political education, and continue to improve and strengthen them.

Thirdly, the essential requirement of the socialism with Chinese characteristics to improve the ideological and political work in colleges. The colleges with socialism with Chinese characteristics must be the colleges under the leadership of the Communist Party of China. This shows that China's colleges cultivate talents for the party and socialism with Chinese characteristics, so the ideological and political work of colleges is very important, treating establishing values and cultivate talents as the basic work, and socialist core values as the leading, persistently cultivate and carry forward the socialist core values, and promote the harmonious and stable development of colleges.

\section{The Impact Factors of Ideological and Political Work in Colleges under the New Situation}

The new social situation will bring opportunities and challenges to the ideological and political work in colleges. It is necessary to correctly understand the factors that affect their work and analyze it so as to ensure that the ideological and political work can form a more scientific and rational working principle in colleges, so as to improve the work efficiency, The promote ideological and political education in colleges.

First of All, The Effect of the social Diversity of Cultural Ecology and Cultural Thought on the Ideological and Political Work in Colleges. The arrival of the information age narrow the distance between the countries of the world, greatly enhancing the exchanges between countries, which makes our country exist social mass culture diversity under the new situation, all kinds of ideas come out endless. Contemporary college students as the main information age, mass culture of its infiltration channels to them are more diversified, and impact range is much wider. The colorful social culture has a great temptation for college students who are not yet stable, and it is easy to make the moral feelings of college students affected by vulgarization, and even occur the situation of the confusion of moral value judgment, which adds to the difficulty of ideological and political work in colleges, need to strengthen and improve the working methods to guide students to establish the correct values.

Second, the Impact of Attitude and System of Colleges on Ideological and Political Work. China's education development is in the critical period of form, the problems of the blurry direction of running a school, the fuzzy educational objectives and inaccurate position for colleges in this period is obvious, leading to phenomenon that some colleges and universities neglect the moral education but pay attention to research, making a lot of colleges pay too much attention to teaching but neglect moral education. This greatly affected the advancement of ideological and political 
work in colleges. In addition, due to the imperfect management system, some colleges neglect the construction of ideological and political work team, and even directly make the professional teachers to carry out the ideological and political work, making ideological and political education just in the form, resulting in ideological and political education empty, students disgust them greatly. Although some schools have set up counselors to specialize in ideological and political education work, but do not pay attention to the improvement of their work quality, and no corresponding assessment and supervision, it is difficult to promote the real improvement and development ideological and political work.

Thirdly, the Influence of the Particularity of Student Groups on the Ideological and Political Work in Colleges. In the new situation, the students entering the university are the new generation after 90s, they were born in the period of China's social and economic development and living standards improved greatly, did not experience the early years of hardships, so their traditional moral feelings are not deep, and because of the implement of family planning policy, their brothers and sisters are not many, most of them are the only child in family, so that they are mostly self-centered, sense of responsibility and collective consciousness is weak, but at the same time they are passionate, active thinking, broad vision, dare to challenge and innovate. In the face of such a group of college students, the ideological and political education in colleges must be improved. The traditional way of education needs to be changed. The way of education can be diversified. Only by constantly strengthening and innovation, can we adapt to the changing needs of college students.

\section{The Principle need to be Followed by the Ideological and Political Work under the new Situation}

In today's diversified society, the realization of the individual value are diversified, which also presents a serious challenge to the ideological and political education in colleges. The ideological and political workers in colleges can not follow the old rules, but also must adhere to the unity of the value of life, in recognition of the status quo of the current objective reality of the cultural diversity, in accordance with scientific and rational principles of work, taking a variety of effective educational channels, to reach to ideological consensus for students, to guide the formation of the correct outlook on life and values.

First, the Ideological and Political Work of Colleges and Universities Must take the Leadership of the Party, Subject To the Direction of Socialism. China's colleges and universities are the focus of the cultivation of outstanding talents, the direction of its ideology is particularly important, at the same time, China's ideological and political education is the propaganda position of Marxism and the core values of socialism in China. Colleges are cultivating talents for socialist construction. The targets of the colleges running schools is to make students adhere to the political position, to cultivate a talented country pillars for the socialist construction, while ideological and political education is the guiding line, firmly adhere to the party leadership, persistently propaganda Marxism-Leninism, Mao Zedong Thought, Deng Xiaoping Theory, the important Thought of Three Represents and the socialist core values, and cultivate high-quality and high-quality talents who serve the socialist construction and people.

Second, the Ideological and Political work in Colleges should adhere to the whole Process to Educate people. Colleges should improve the ideological and political education of all teachers, the ideological value work is integrated into the various stages and aspects of teaching, from the professional courses of students to scientific research, then to the campus life, it can not lack the educational function. Through adopting to effective management measures, to form long-term mechanism of teaching and educating people, scientific research educating people, practicing education, management education, service education, cultural education, organization education. The values is not established on day, it is formed in the long-term life and learning gradually, the effective time of the ideological and political work to students is limited, we must adopt a full range of long-term mechanism in order to ensure the effect of ideological and political education, from the essence to enhance the students' ideological understanding. 
Third, the Ideological and Political Work should follow the Law of education and Student Growth. when carry out the ideological and political work in colleges, we should pay attention to grasp the teachers and students of their own ideological characteristics and their different development needs, combining theoretical education and practical experience, to meet the general requirements at the same time also need to pay attention to the necessity of classification guidance, which will improve the scientific and rational level of ideological and political work. With the arrival of the information age, the horizons of students are increasingly open, the contact with the increasingly range of knowledge become much wider, so in its ideological and political education, we should follow its growth law, give the learning initiative to the students, let them take the initiative to find the problem, ask questions, teachers guide them to solve the problem, imperceptibly instill ideological values.

Fourth, the Ideological and Political Work in Colleges should Adhere to the Principle of Reform and Innovation. Since the founding of the PRC, China's ideological and political education in colleges will be guided by Marxism. With the development of our party and government, the content of ideological and political education in colleges is constantly enriched, and the way of teaching should be reformed and innovated with the times. The traditional ideological and political education in colleges is based on the teaching of theoretical knowledge, supplemented by the form of closed-book examination, this model is conducive to meet the general needs of education work, but the effect that the form is larger than the content, under the new situation the ideological and political work mode should be improved, using case teaching methods to teach theoretical knowledge, in order to stimulate students' interest in learning, to carry out practical activities for students to experience and think; ideological and political workers should change their ideas, clearly know the goal of ideological and political education is the values education rather than just knowledge education, so that students and workers come together to become the two main body of the teaching; in the way of examination, knowledge detection and practical activities can be combined with experience; In addition, colleges can carry more campus theme activities, enrich the school ideological education construction, form a good campus culture atmosphere, so that students are imperceptibly affected in life, establish a healthy and good ideas fundamentally.

\section{Conclusion}

In this society, the international situation is stable but followed by changing, the conflict between different countries are unremitting, different ideological culture and social thinking are pouring into our country, which makes great clash of ideas to our young people, In this context, the ideological and political education in colleges is of great significance. As the concentrated place of social personnel training, colleges have the responsibility and obligation to guide students to establish the correct values, adhere to treat the Marxist as the guide and the core values of socialism as the center, and constantly strengthen and improve the ideological and political work in colleges, and strive to cultivate and supply all-round talents with abundant knowledge and noble political idea for socialism construction.

\section{References}

[1] $\mathrm{Wu}$ Huaiyou. The action program of ideological and political work under the new situation-learning the speech of $\mathrm{Xi}$ Jinping in the national ideological and political work conference, Mao Zedong Research, 2017, 2

[2] Xiong Mei, Yao Xiaobo. The effective way of ideological and political education in colleges under the new situation, Journal of Xichang University, 2016, 28, 2

[3] Zhang Qiaofu. How to do a good job of ideological and political education in colleges under the new situation. Learning Theory, October 2014.

[4] Liu Xiaojun. Discussion on the innovation of college students ideological and political work 
under the new situation, Journal of Inner Mongolia Medical College, October 2012, 34, 5: 792-794.

[5] He Yujie, Discussion on the innovation of ideological and political education work, China Higher Education Research, 2011, 4: 17-18

[6] Jiang Guiji. Analysis on how to strengthen and improve the ideological and political education of college students, Hetao University Distance Education College, 2011.

[7] Guo Yuzhi. Study on ideological and political work innovation, Beijing Jiaotong University, $2010,7$.

[8] Ding Ping. Thinking on practical significance of the ideological and political education under the new situation, Shandong Province Youth Management Cadre College Journal, 2010,3: 91-93

[9] Yu Hailong. Study on the effectiveness of college counselors ideological and political education work under the new situation, Anhui University of Technology, February 2014

[10] Zhou Qunyang, Wang Jian. Study on the effectiveness of college counselor ideological and political education behavior, the Journal of Hunan City University, 2011 (01): 101-104. 